\title{
Outcomes in CAH: Need for Evidence-Based Estimates
}

\author{
Scott D. Grosse ${ }^{\mathrm{a}}$ Guy Van Vliet ${ }^{\mathrm{b}}$ \\ ${ }^{a}$ National Center on Birth Defects and Developmental Disabilities, Centers for Disease Control and Prevention,

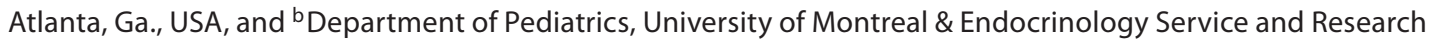 \\ Center, Sainte-Justine Hospital, Montreal, Que., Canada
}

We appreciate the many efforts of the CARES Foundation, Inc. on behalf of children with $\mathrm{CAH}$ and recognize that the death of even one child with this preventable outcome is a tragedy. Preventive programs and policies can be most effectively developed on an evidence-based foundation, and the available data support our conclusion that infant mortality in classical $\mathrm{CAH}$ is $\leq 4 \%$ in North America and Europe. Additional supporting data come from a recent study of stored blood spot specimens for unexplained infant deaths in Austria and the Czech Republic that found about one fifth as many cases of $\mathrm{CAH}$ as had been expected on the basis of expert opinion [1]. Out of more than 2 million births during a 13 -year period, there were 3 unexplained deaths due to $\mathrm{CAH}$, or $2 \%$ of the expected number of children with $\mathrm{CAH}$.

We agree with Ms. Leight that there should also be a systematic study of a sample of all infant deaths to determine the frequency of death due to CAH. As stated in our article: 'One way to ascertain such deaths in cohorts not screened for $\mathrm{CAH}$ at birth is to retrieve stored dried blood spot filter paper cards for children who died in infancy or early childhood and test for the presence of $\mathrm{CAH}$, including analysis of CYP21 mutations specific for SW-CAH.' We would be pleased to collaborate with CARES Foundation, Inc. to identify other research needs as well.
The statement that among children born in United States jurisdictions that screened for CAH in 2006 'Over 56\% of presumed cases of CAH went undetected' is incorrect. The sensitivity of newborn screening for classical CAH is extremely high, essentially $100 \%$ for salt-wasting $\mathrm{CAH}$ [2]. The 'National Newborn Screening and Genetics Resource Center records' cited by Ms. Leight come from the US National Newborn Screening Information System (NNSIS) database to which states voluntarily report data and which is regularly updated [3]. The NNSIS as of April 6, 2007 , included a total of 150 children born in 2006 with confirmed classical CAH. Because a number of states had either not yet reported data or reported incomplete data for CAH diagnoses in 2006, the ultimate number will be substantially larger. NNSIS data for 2005 included 180 children confirmed with classical CAH born in 30 states with a total of 2.8 million births that were screened for CAH, or 1 in 15,700 births.

We share Ms. Leight's concern about the plight of children with $\mathrm{CAH}$ born in low-income countries, among whom the rate of mortality is likely to be quite high. On the other hand, the most cost-effective approach to reducing $\mathrm{CAH}$ mortality in such countries needs to be carefully considered along with the availability of treatment following identification of $\mathrm{CAH}$. This requires data on outcomes with and without screening. Migeon and Donohoue
[4] suggested that 'limited health care funds would be more appropriately spent to further increase the awareness of the problem through education rather than to screen all newborns'. Our study indicates that many, perhaps most, CAH-related deaths can be prevented through heightened clinical awareness and prompt treatment.

\section{References}

1 Strnadova KA, Votava F, Lebl J, Muhl A, Item C, Bodamer OA, et al: Prevalence of congenital adrenal hyperplasia among sudden infant death in the Czech Republic and Austria. Eur J Pediatr 2007; 166:1-4.

2 Votava F, Torok D, Kovacs J, Moslinger D, Baumgartner-Parzer SM, Solyom J, et al: Estimation of the false-negative rate in newborn screening for congenital adrenal hyperplasia. Eur J Endocrinol 2005;152:869-874.

3 National Newborn Screening and Genetic Resource Center: National Newborn Screening Information System. Available at: http:// www2.uthscsa.edu/nnsis/. Accessed April 6, 2007.

4 Migeon CJ, Donohoue PA: Adrenal disorders; in Kappy MS, Blizzard RM, Migeon CJ (eds): The Diagnosis and Treatment of Endocrine Disorders in Childhood and Adolescence, ed 4. Springfield, Thomas, 1994, pp 717-856.

\section{KARGER}

Fax +4161306 1234 E-Mail karger@karger.ch www.karger.com
(C) 2007 S. Karger AG, Basel 0301-0163/07/0684-0203\$23.50/0

Accessible online at: www.karger.com/hre
Dr. Scott D. Grosse

National Center on Birth Defects and Developmental Disabilities

Centers for Disease Control and Prevention

1600 Clifton Road, MS E87, Altanta, GA 30333 (USA)

Tel. +1 404498 3074, Fax +1 404498 3070, E-Mail sgrosse@cdc.gov 